\title{
A Spatial Index for Identifying Opportunity Zones for Woody Cellulosic Conversion Facilities
}

\author{
Xia Huang, ${ }^{1}$ James H. Perdue, ${ }^{2}$ and Timothy M. Young ${ }^{1}$ \\ ${ }^{1}$ Center for Renewable Carbon, University of Tennessee, Knoxville, TN 37996-4570, USA \\ ${ }^{2}$ USDA Forest Service, Southern Research Station, 2506 Jacob Drive, Knoxville, TN 37996-4570, USA
}

Correspondence should be addressed to Timothy M. Young, tmyoung1@utk.edu

Received 10 July 2012; Revised 26 September 2012; Accepted 10 October 2012

Academic Editor: John Stanturf

Copyright (C 2012 Xia Huang et al. This is an open access article distributed under the Creative Commons Attribution License, which permits unrestricted use, distribution, and reproduction in any medium, provided the original work is properly cited.

\begin{abstract}
A challenge in the development of renewable energy is the ability to spatially assess the risk of feedstock supply to conversion facilities. Policy makers and investors need improved methods to identify the interactions associated with landscape features, socioeconomic conditions, and ownership patterns, and the influence these variables have on the geographic location of potential conversion facilities. This study estimated opportunity zones for woody cellulosic feedstocks based on landscape suitability and market competition for the resource. The study covered 13 Southern States which was a segment of a broader study that covered 33 Eastern United States which also included agricultural biomass. All spatial data were organized at the 5-digit zip code tabulation area (ZCTA). A landscape index was developed using factors such as forest land cover area, net forest growth, ownership type, population density, median family income, and farm income. A competition index was developed based on the annual growth-toremoval ratio and capacities of existing woody cellulosic conversion facilities. Combining the indices resulted in the identification of 592 ZCTAs that were considered highly desirable zones for woody cellulosic conversion facilities. These highly desirable zones were located in Central Mississippi, Northern Arkansas, South central Alabama, Southwest Georgia, Southeast Oklahoma, Southwest Kentucky, and Northwest Tennessee.
\end{abstract}

\section{Introduction}

Energy, its availability and use, is fundamental to a sustainable economy. The 20th century was marked by rapid growth and increased prosperity in the world. By 2020, the world's energy consumption is predicted to be $40 \%$ higher than it is today [1]. Key sources of oil are located in complex geopolitical environments that increase economic risk. Since the 1970s, macroeconomists have viewed changes in the price of oil as an important source of economic fluctuations, as well as a paradigm for global shock, likely to affect many economies simultaneously [2].

Renewable energy is projected to be one of the fastest growing industries in the US agricultural and forest sectors. As Elbehri [3] noted replacing petroleum products with biobased fuels and energy presents several technical, economic, and research challenges, one of which is the availability of biomass feedstock. Elbehri [3] also noted that lack of biomass production capacity, high relative costs of production, logistics, and transportation of feedstocks are all potential constraints that need to be better understood. This study directly addresses Elbehri's [3] thesis by developing physical landscape and socioeconomic data for use by decision-makers interested in identifying opportunity zones for biomass-using facilities.

A plethora of literature exists on the economic availability of biomass [4-18]. A recent report by the US Department of Agriculture and Department of Energy concluded that 1.3 billion tons of biomass are available annually for energy production $[18,19]$.

A major difficulty addressed in this study that biomass production and access to this biomass in the field are not always directly related in a spatial context to decisionmakers interested in mill siting. Improved information and methods for biomass markets that display and visualize the 
costs of supply and logistics from farm to forest gate to collection or conversion facilities may improve knowledge essential for market formation. The supply of biomass may be more constrained when relying on a supply network that is independent of the production facility for the raw material, for example, facility relies on gate prices and does not have company or contract-engaged suppliers. Decisions made in response to societal objectives frequently result in (more or less) permanent physical occupation of areas of land, for example, buildings, roadways, preserves, and so forth. Therefore, emerging opportunities that compete against existing uses of property or raw resources are often socially constrained or permanently denied regardless of economic viability.

This study identifies opportunity zones in a spatial context for woody cellulosic feedstocks available to potential conversion industries, for example, biorefineries, wood pellet mills, biopower, and so forth. The opportunity zones are derived from the use of landscape suitability and competition indices. Landscape features (measure to which a competing land use is physically restricted by current land use) may adversely impact economically viable competing uses of property and thereby restrict biomass access and positive location decisions. Spatial competition is particularly important for access to biomass resources. Existence of competing biomass using facilities reduces the probability of making a positive location decision and this impact decreases with distance from competition.

Specific objectives of the study were (1) compile data on the physical and socioeconomic characteristics of the landscape and display this data in a spatial context at the 5-digit zip code tabulation resolution for 33 eastern United States; (2) develop an index from the spatial data that would discriminate the landscape to identify opportunity zones for biomass-using facilities; and (3) integrate objectives (1) and (2) with the Biomass Site Assessment Tool (BioSAT), http://www.biosat.net/, as an example of application of the spatial data for practitioners.

\section{Methods}

2.1. Datasets. This study involved organizing large volumes of data collected from various sources, including the US Census Bureau [20], US Forest Service [21], US National Land Cover Database [22], US National Elevation Dataset [23], US Department of Agriculture National Agricultural Statistic Service [24], US Environmental Protection Agency [25], and state mill directories.

Another resource that was used to illustrate how this data could be helpful to possible users was the integration of the BioSAT model with the study [26]. The BioSAT model was used in this study to estimate the availability of woody cellulose for procurement zones within a $128.8 \mathrm{~km}$ ( 80 mile) one way travel distance which may not be concentric, that is, the shape of such zones rely on the available transportation network and biomass supply. National forests, parks, urban areas, and other restricted areas were not considered in BioSAT when estimating availability. Travel times and distances were estimated from Microsoft MapPoint 2006. Road networks in MapPoint were a combination of the Geographic Data Technology, Inc. (GDT) and Navteq data. GDT data were used for rural areas and small to medium size cities (e.g., rural paved two-lane roads, privately owned driveway, pedestrian walkway). Navteq data were used for major metropolitan areas (e.g., roads with turn restrictions, physical barriers and gates, one-way streets, restricted access and relative road heights). In the BioSAT model, estimates of all-live total biomass, as well as average annual growth, removals, and mortality were obtained from the Forest Inventory and Analysis Database (FIADB) version 3.0.

All records were organized at the US Census Bureau 5digit ZIP Code Tabulation Area (ZCTA) level [20]. There were 10,016 ZCTAs in the 13-state (Alabama, Arkansas, Florida, Georgia, Kentucky, Louisiana, Mississippi, North Carolina, Oklahoma, South Carolina, Tennessee, Texas, Virginia) study region which corresponded to 10,016 potential analytical polygons or opportunity zones for biorefineries using woody cellulose. The average area size for 5-digit ZCTAs in the 13-state study regions was $209.84 \mathrm{~km}^{2}$. Twelve variables (Table 1) were used in a spatial context as geographical landscape and socioeconomic factors with the BioSAT model in determining opportunity zones.

The research methodology used in this study has four main components: (1) estimation of forest biomass availability; (2) measurement of landscape suitability of forest biomass access; (3) analysis of a spatial market competition for forest biomass resources; and (4) visualization of biomass opportunity zones. Each of these components is described in the following section.

2.2. Estimation of Biomass Availability. Forest biomass annual growth and removal quantity data were collected at the county level from Forest Inventory and Analysis Database (FIADB) version 3.0 (Figure 1(a)), and reallocation was done for each of the 10,016, 5-digit ZCTAs using a geographic information system (GIS) technology. National land cover data [22] and digital raster map were used to identify forestland. In the digital raster map, each pixel represents one particular land cover class, that is, water, urban, forest, or cropland, and so forth (Figure 1(b)). Forest biomass annual growth and removal quantities were proportionally allocated to each 5-digit ZCTA using the county boundary, 5-digit ZCTA, and the land cover image data with GIS spatial overlay techniques.

Due to the mismatch of county boundary and 5-digit ZCTA (i.e., some 5-digit ZCTAs cross county), each forest biomass county was split into multiple area parts via the 5-digit ZCTA area shape and assigned a unique 5-digit ZCTA identifier. By overlaying each area part with the land cover image layer, the numbers of pixels in all land cover classes within each area were estimated (Figure 1(c)). By summing up the pixels of deciduous forest, evergreen forest, and mixed forest, which together represented forestland, in the unit of county, a forestland pixel ratio for each area part to its belonging county was calculated and the forest biomass quantity in every area part was derived for this pixel ratio (Figure $1(\mathrm{~d})$ ). A summed quantity value for all area 
TABLE 1: Geographical landscape and socio-economic factors used in study.

\begin{tabular}{|c|c|c|c|}
\hline Variable & Original data resolution & Unit & Data sources \\
\hline Population density & 5-digit ZCTA & People/mile ${ }^{2}$ & $\begin{array}{l}\text { U.S. Census Bureau (2010) population } \\
\text { density in each 5-digit ZCTA. }\end{array}$ \\
\hline Farm net income & County & Dollar & $\begin{array}{l}\text { USDA NASS Census Agriculture (2007) } \\
\text { farm net income in each county. }\end{array}$ \\
\hline Road density & 5-digit ZCTA & $\mathrm{km} / \mathrm{km}^{2}$ & U.S. Census Bureau (2010) road length \\
\hline \multicolumn{4}{|c|}{ Crop cultivated land area ratio } \\
\hline Forest land area ratio & 5-digit ZCTA & Percent & $\begin{array}{l}\text { U.S. National land Cover Database } \\
\qquad(2006)\end{array}$ \\
\hline \multicolumn{4}{|l|}{$\begin{array}{l}\text { Urban Land area ratio } \\
\text { Water area ratio }\end{array}$} \\
\hline Slope & 5-digit ZCTA & Percent & $\begin{array}{l}\text { U.S. National Elevation Dataset (1999) } \\
\text { NED } 1 \text { arc second }\end{array}$ \\
\hline Ecoregions Level III & Ecoregions & - & U.S. EPA (2011) \\
\hline $\begin{array}{l}\text { Timberland annual } \\
\text { growth-to-removal ratio }\end{array}$ & County & - & $\begin{array}{l}\text { Forest Inventory and Analysis_-The } \\
\text { Timber Products Tools (TPO) (2009) }\end{array}$ \\
\hline Lands in public preserves & 5-digit ZCTA & - & U.S. Forest Service (2009) \\
\hline $\begin{array}{l}\text { Primary wood-using mill } \\
\text { locations }\end{array}$ & 5-digit ZCTA & - & $\begin{array}{l}\text { U.S. Forest Service (2009) and state mill } \\
\text { directories }\end{array}$ \\
\hline
\end{tabular}

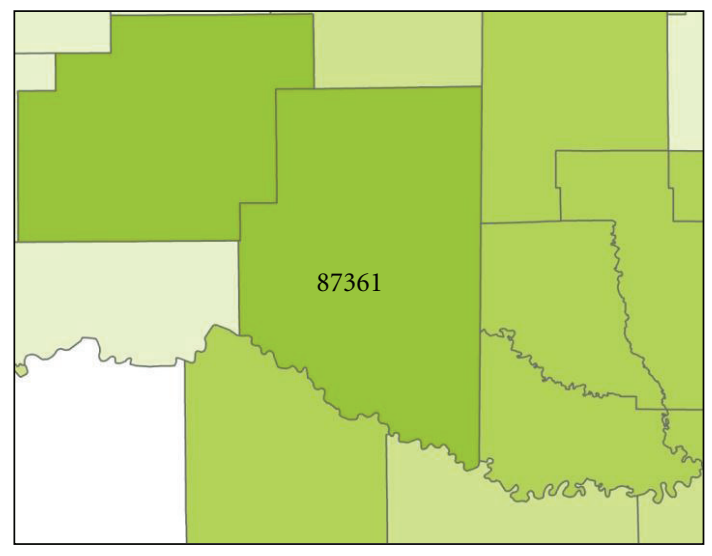

(a) Illustration of county forest biomass quantity

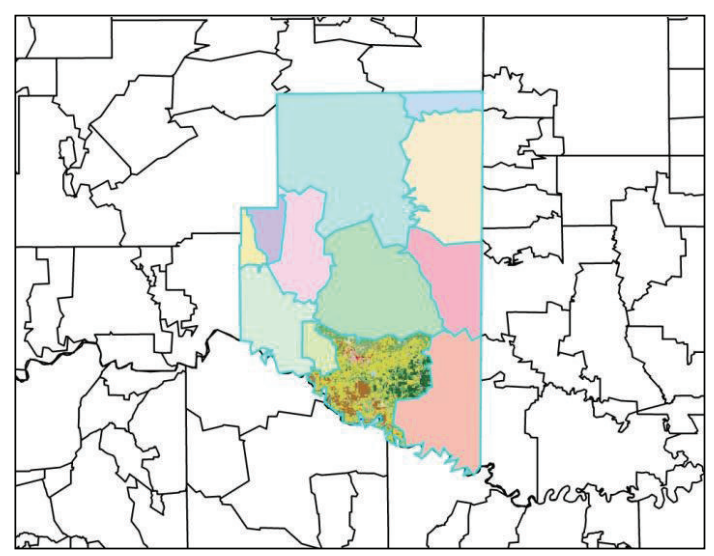

(c) Land cover for 5-digit ZCTA boundary

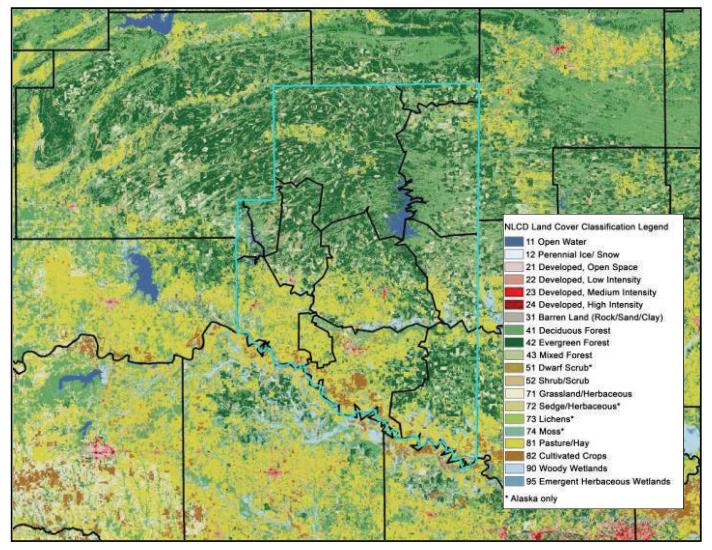

(b) Land cover map and county boundary

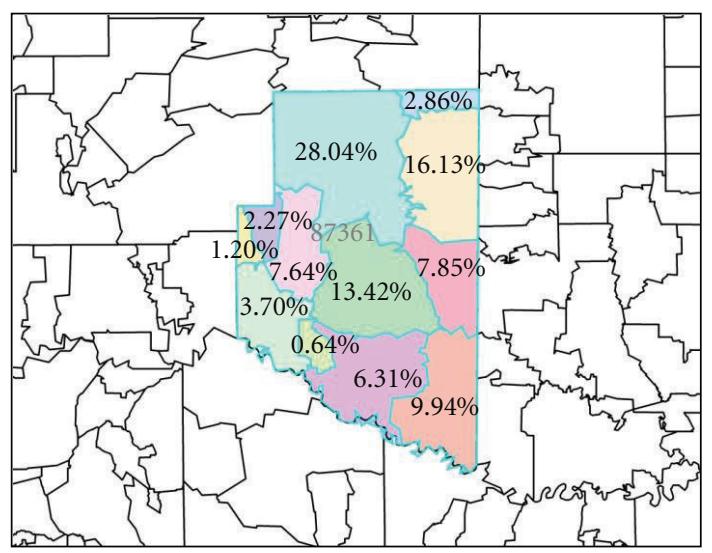

(d) Forest biomass allocation by 5-digit ZCTA

FIGURE 1: Illustration of forest biomass allocation at the level of 5-digit ZCTA. 
parts belonging to the same 5-digit ZCTA was then calculated as the forest biomass quantity in this 5-digit ZCTA.

2.3. Landscape Suitability Index. The availability of forest biomass, as well as other forest resources, is physically constrained by a set of factors from the natural and socialeconomic environment [27]. The landscape suitability index explores the biophysical environment and its impacts on forest biomass access in a spatial context. Several criteria and their combinations including current land use characteristics, land ownership, and socialeconomic and/or legal constraints were used to preselect opportunity zones for forest biomass using facilities. The suitability index assumes that the presence of harvestable forests, access to abundant forest resource supply, and minimal socialeconomic restrictions from human activity (e.g., urban development, suburban sprawl, national parks, etc.) provides optimal conditions for woody cellulosic conversion facilities. Attributes of "forest land area ratio," "slope," as well as "suitable ecoregions for forests" determined the spatial degree of the presence of harvestable forests. The attribute "timberland annual growthto-removal ratio" was an indicator of forest net growth. The variables "population density," "farm net income," "median family income," and "road density" were used to estimate socialeconomic indicators.

The final suitability index value was organized into ordinal levels based on expert judgment to estimate the amount and accessibility of forest biomass given the aforementioned possible constraints (Table 2). "High" suitability was considered to be a suitable opportunity zone for woody cellulosic conversion facilities relative to "moderate" or "low" suitability which would be less desirable as potential opportunity zones for woody cellulosic conversion facilities. "Unsuitable" land areas as defined by EPA ecoregions classification (The US EPA ecological regions (ecoregions) comprehensively categorize and outline main features of each unit across North America according to a variety of biological, physical, and human factors. Each ecoregion marks a geographic area with a shared climate, terrain and similar vegetation, hydrology, wildlife and land use/human activities throughout.) [25] depicted areas that are not ecologically suitable for forest production, for example, desert in western Texas, or mountain tops of Smoky Mountains. "Exclusion" zones referred to land areas that will not support forest production given socioeconomic and/or ownership type, for example, national parks, military bases, or urban areas with population density over 58 people per square kilometer (58 people $/ \mathrm{km}^{2}$ equals to 150 people/mile ${ }^{2}$ ) [28], see Figure 2.

2.4. Competition Index. Potential forest biomass availability is also strongly influenced by the level of competition for the resource. Resource competition is usually negatively correlated with forest biomass availability unless the potential supply is a byproduct of existing harvesting operations such as forest residues [29].

A "zone-of-influence" model was developed in this study. The zone-of-influence model assumes the procurement zones associated with existing demand points or mills may
TABLE 2: Definitions of landscape suitability index.

\begin{tabular}{ll}
\hline Level & Description \\
\hline High suitability & $\begin{array}{l}\text { Lands suitable for forest production only, for } \\
\text { example, forests of northern Minnesota }\end{array}$ \\
\hline $\begin{array}{l}\text { Moderate } \\
\text { suitability }\end{array}$ & $\begin{array}{l}\text { Lands that have moderate capability for being } \\
\text { only in forest production }\end{array}$ \\
\hline Low suitability & $\begin{array}{l}\text { Lands may be easily converted to agricultural } \\
\text { production from forestland }\end{array}$ \\
\hline Unsuitable & $\begin{array}{l}\text { Land areas as defined by ecoregion } \\
\text { classification that are not suitable for forest or } \\
\text { agricultural production, for example, desert in }\end{array}$ \\
& $\begin{array}{l}\text { western Texas, mountain tops of Smoky } \\
\text { mountains }\end{array}$ \\
\hline Exclusion & $\begin{array}{l}\text { Land areas that will not support forest or } \\
\text { agricultural production given socioeconomic } \\
\text { and/or legal constraints, for example, national } \\
\text { parks, military bases, urban areas with } \\
\text { population density }>58 \text { people } / \mathrm{km}^{2}[28], \text { and } \\
\text { so forth }\end{array}$ \\
\hline
\end{tabular}

not be concentric and that neighboring mills have procurement zones that occupy the same space and overlap [2931]. The zone of influence model developed in this study used existing primary wood-using operating capacities (e.g., sawmills, OSB mills, pulp, and paper mills, etc.) assuming $80 \%$ utilized capacity, together with the forest annual growth-to-removal ratio to estimate the intensiveness of competition for the forest biomass resource (Figure 3). (A $128.8 \mathrm{~km}$ one-way haul distance given the road network surrounding each facility was assumed). Mathematically, the intensiveness of competition was defined as a percent of the sum of the demand capacity within a fixed driving distance over the supply annual net growth for each 5-digit ZCTA. (The sum of demand capacities was the total value of allocated capacities, assuming an $80 \%$ utilization rate). The fixed driving distance was $128.8 \mathrm{~km}$ one-way haul distance estimated from Microsoft MapPoint 2006 road network. The initial value was adjusted by the annual net growth and growth-to-removal ratio. Each facility's operating capacity, based on the forest area coverage characteristics, was proportionally allocated to the neighboring supply 5-digit ZCTAs for the fixed driving distance.

Six ordinal levels were developed defining the intensity of competition based on expert judgment (Table 3). Codes 1 to 5 are considered the regions where a positive annual net forest growth existed, but the intensity of competition for the resource was different. For example, the "highest" intensity of competition for the resource was considered regions where the adjusted annual operating capacities of all primary woodusing facilities exceeded the annual net forest growth of the forest resources. The "least" intensive competitive regions were those where only $10 \%$ or less of the annual net forest growth was consumed by the adjusted annual operating capacities of primary wood-using facilities. Code 6, "No or negative supply net growth", considered the regions where either no forest resources existed or forest annual mortality rate exceeded the annual growth rate. 


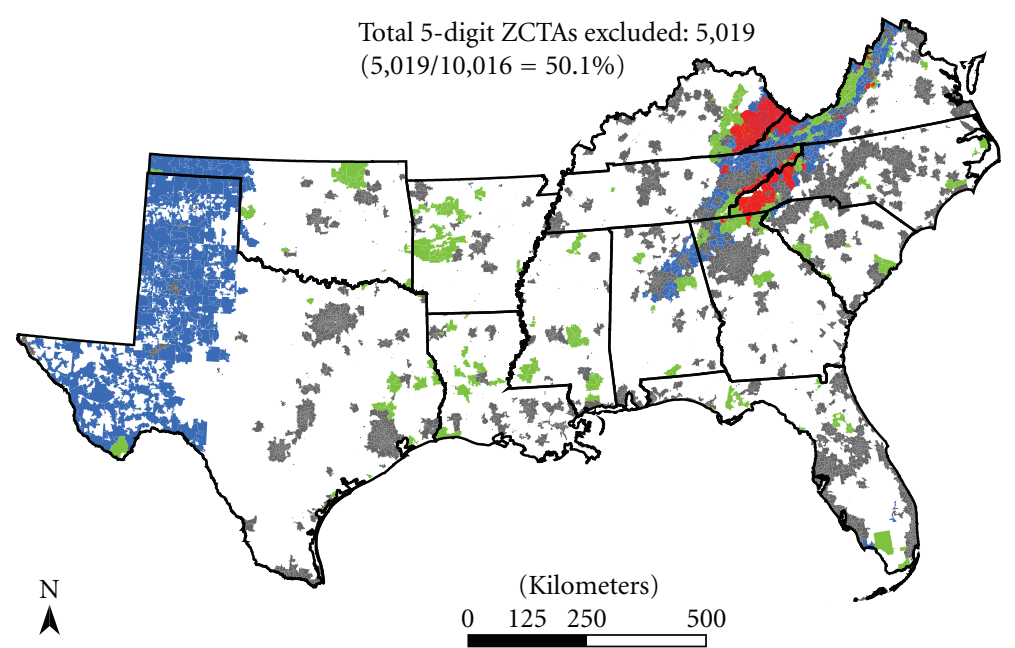

Federal lands

Population $>58$ people/sq km (150 people/mile)

Slope $>30 \%$

Unsuitable ecoregions

FIGURE 2: 5-digit ZCTAs excluded in the 13-state study region.

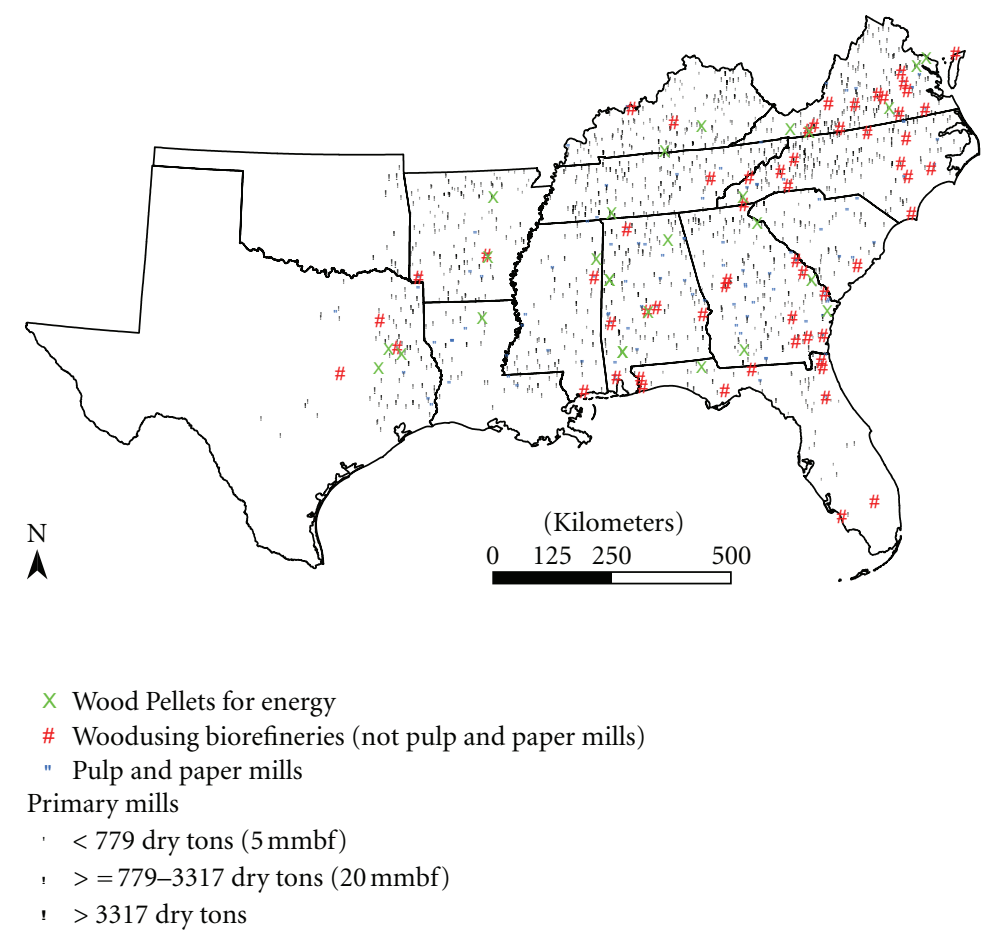

Figure 3: Primary wood-using facilities in the 13-state study region.

2.5. Visualization of Opportunity Zones. GIS methods are highly effective for visualization mapping of spatial opportunity zones for biomass availability and accessibility when a study area consists of more than 10,000 location units (5-digit ZCTAs), as was the case in this study. Two sets of maps were produced in this study. The first set was spatial opportunity zones for woody cellulosic conversion facilities using the aforementioned landscape suitability and competition indices. The second set of maps illustrates the spatial pattern of the competition intensity for the resource 
TABLE 3: Definitions of competition index on resource utilization.

\begin{tabular}{ll}
\hline Code & Description \\
\hline 1 & $\begin{array}{l}\text { Least competitive-less than 10\% supply net growth } \\
\text { consumed by existing capacity, and annual supply net } \\
\text { growth over 10,000 dry ton/year, and timberland } \\
\text { annual growth-to-removal ratio greater than 1.5 }\end{array}$ \\
\hline & $\begin{array}{l}\text { Less moderate competitive-less than 50\% supply net } \\
\text { growth consumed by existing capacity, and positive } \\
\text { annual supply net growth, and timberland annual } \\
\text { growth-to-removal ratio greater than 1.0 }\end{array}$ \\
\hline 3 & $\begin{array}{l}\text { Moderate competitive-less than 100\% supply net } \\
\text { growth consumed by existing capacity, and positive } \\
\text { annual supply net growth, and timberland annual } \\
\text { growth-to-removal ratio greater than 1.0 }\end{array}$ \\
\hline 4 & $\begin{array}{l}\text { More moderate competitive-less than } 100 \% \text { supply net } \\
\text { growth consumed by existing capacity, and positive } \\
\text { annual supply net growth, and timberland annual } \\
\text { growth-to-removal ratio less or equal than 1.0 }\end{array}$ \\
\hline 5 & $\begin{array}{l}\text { Most competitive-equal or more than 100\% supply net } \\
\text { growth consumed by existing capacity }\end{array}$ \\
\hline 6 & $\begin{array}{l}\text { No or negative supply net growth (or timberland annual } \\
\text { growth-to-removal ratio equals to 0) }\end{array}$ \\
\hline
\end{tabular}

assuming a fixed haul distance from each existing woodusing facility.

\section{Results and Discussion}

3.1. Opportunity Zones Using the Landscape Suitability Index. The four indicators of "federal lands," "population density," "slope," and "unsuitable ecoregions" were used to "exclude" ZCTAS from the study region. "Federal lands" included lands in ownership by the Bureau of Indian Affairs, Department of Defense, Fish and Wildlife Service, Forest Service, National Aeronautics and Space Administration, National Park Service, Tennessee Valley Authority, and US Department of Agriculture Research Center. ZCTAs with "population density" ( $>58$ people $/ \mathrm{km}^{2}$ ) were excluded given the results of previous research [28]. ZCTAs with slopes greater than $30 \%$ were excluded given the limitations of ground-based harvest capabilities in the Eastern United States and also given the results of previous research related to soil disturbance [32]. Seven "unsuitable" Level III ecoregions excluded areas from mountain tops in Smoky Mountains, grassland in West Oklahoma, deserts in West Texas, and marshland and swampland in Southern Florida [25]. These four criteria together resulted in an initial exclusion of 5,019, 5-digit ZCTAs or approximately $50.1 \%$ of the total 5-digit ZCTAs in the 13-state study region (Figure 2).

The criteria to assess the other four levels of landscape suitability are given in Table 4. Two threshold values for "forest area ratio" (10\% and 30\%) were selected based on the definition of Food and Agriculture Organization of the United Nations [33] and United Nations Framework for Climate Change Convention [34]. (Food Agriculture Organization of the United Nations [33] defines forests as "lands with a tree crown cover equal or more than $10 \%$ of the area". United Nations Framework for Climate Change
TABLE 4: Criteria for four levels of landscape suitability.

\begin{tabular}{|c|c|}
\hline Level & Criteria \\
\hline $\begin{array}{l}\text { High } \\
\text { suitability }\end{array}$ & $\begin{array}{l}\text { Forest area ratio greater than } 30 \% \text {; and timberland } \\
\text { annual growth-to-removal ratio greater than } 1.5 \text {; } \\
\text { and ecoregions defined as mostly forestland; and } \\
\text { slope lower than } 30 \% \text {; } \\
\text { and population density less than } 39 \text { people } / \mathrm{km}^{2}\end{array}$ \\
\hline $\begin{array}{l}\text { Moderate } \\
\text { suitability }\end{array}$ & $\begin{array}{l}\text { Forest area ratio greater than } 10 \% \text {; and timberland } \\
\text { annual growth-to-removal ratio greater than } 1 \text {; and } \\
\text { ecoregions defined suitable for forestland; and slope } \\
\text { equal or lower than } 30 \% \\
\text { and population density equal or less than } \\
58 \text { people } / \mathrm{km}^{2}\end{array}$ \\
\hline $\begin{array}{l}\text { Low } \\
\text { suitability }\end{array}$ & $\begin{array}{l}\text { Forest area ratio greater than } 10 \% \text {; and timberland } \\
\text { annual growth-to-removal ratio equal or less than } 1 \text {; } \\
\text { and ecoregions defined suitable for forestland or } \\
\text { cropland; and slope equal or lower than } 30 \% \text { and } \\
\text { population density equal or less than } 58 \text { people } / \mathrm{km}^{2}\end{array}$ \\
\hline $\begin{array}{l}\text { Unsuitable } \\
\text { for forests }\end{array}$ & $\begin{array}{l}\text { Forest area ratio equal or less than } 10 \% \text {; or } \\
\text { timberland annual growth-to-removal ratio less than } \\
0 \text {; or ecoregions defined as mostly cropland; or } \\
\text { negative farm net income but median family income } \\
\text { greater than } \$ 49,445 \text { or road density higher than } \\
5 \mathrm{~km} / \mathrm{km}^{2}\end{array}$ \\
\hline
\end{tabular}

Convention [34] defines natural forests should be with greater than $30 \%$ of tree canopy cover for deciduous forests, evergreen forests, and mixed forests). Three threshold values for "timberland annual growth-to-removal ratio" $(0,1.0$, and 1.5) were used to measure existing forest annual net growth and the potential for further harvesting. An annual net growth-to-removal ratio of 1.0 indicates forest net growth equals removals. A ratio of 1.5 indicates that $50 \%$ of the forest annual net growth exceeds removals which in this study was assumed a desirable metric. "Slope less than 30\%" was considered slopes where timber harvesting activities were barely impacted [35]. US Census Bureau [36] found the transition between rural and urban land uses occurred when the population density was about 39 people $/ \mathrm{km}^{2}$ (equivalent to 100 people/mile ${ }^{2}$ ). "Farm net income" and "median family income" together were used as a proxy measure to separate farm and nonfarm population. Median family income exceeding $\$ 49,445$ (i.e., the median value of median family income in 2010 [20]) and income from nonfarm sources greater than farming (i.e., negative farm net income) indicated most family dependent on nonfarm income. "Road density", which is highly correlated with population density, was also considered as a proxy or indirect measure of forest parcel size [37]. A threshold value of exceeding $5 \mathrm{~km} / \mathrm{km}^{2}$ was considered as very high road density and that when this level of road density occurs the probability of forest harvesting dramatically declines [38, 39].

Regions that had forest area ratio greater than $30 \%$, timberland annual growth-to-removal ratios greater than 1.5 , ecoregions defined as mostly forestland, slopes less than $30 \%$, and less than 39 people $/ \mathrm{km}^{2}$ were considered areas that were highly suitable for forest productions. Based on these criteria, high suitable opportunity zones for facilities 
TABLE 5: Criteria for four levels of the combined landscape suitability and competition indices.

\begin{tabular}{|c|c|c|}
\hline Level & Landscape suitability criteria & Competition criteria \\
\hline High suitability & $\begin{array}{l}\text { Forest area ratio greater than } 30 \% \text {; and timberland annual growth-to-removal } \\
\text { ratio greater than } 1.5 \text {; and ecoregions defined as mostly forestland; and slope } \\
\text { lower than } 30 \% \text {; and population density less than } 39 \text { people } / \mathrm{km}^{2}\end{array}$ & Competition index $\leq 4$ \\
\hline Moderate suitability & $\begin{array}{l}\text { Forest area ratio greater than } 10 \% \text {; and timberland annual growth-to-removal } \\
\text { ratio greater than } 1 \text {; and ecoregions defined suitable for forestland; and slope } \\
\text { equal or lower than } 30 \% \text { and population density equal or less than } \\
58 \text { people } / \mathrm{km}^{2}\end{array}$ & Competition index $\leq 4$ \\
\hline Low suitability & $\begin{array}{l}\text { Forest area ratio greater than } 10 \% \text {; and timberland annual growth-to-removal } \\
\text { ratio equal or less than } 1 \text {; and ecoregions defined suitable for forestland or } \\
\text { cropland; and slope equal or lower than } 30 \% \text { and population density equal or } \\
\text { less than } 58 \text { people } / \mathrm{km}^{2}\end{array}$ & Competition index $\leq 5$ \\
\hline Unsuitable for forests & $\begin{array}{l}\text { Forest area ratio equal or less than } 10 \% \text {; or timberland annual } \\
\text { growth-to-removal ratio less than } 0 \text {; or ecoregions defined as mostly cropland; } \\
\text { or negative farm net income but median family income greater than } \$ 49,445 \text { or } \\
\text { road density higher than } 5 \mathrm{~km} / \mathrm{km}^{2}\end{array}$ & Competition index $\leq 6$ \\
\hline
\end{tabular}

relying on woody cellulosic feedstocks were located along the Central Mississippi, northwest and southeast Alabama, north Arkansas, west Georgia, east Oklahoma, and areas in Kentucky, Tennessee and Virginia close to Smokey Mountains (Figure 4).

A strength of the data analyses was that socioeconomic data which is collected at the 5-digit ZCTA resolution was incorporated in the data overlays and therefore were not aggregated which maintained data integrity for these variables. A potential weakness of the study was the deaggregation of forest inventory data which implies that the opportunity zones have improved validity as the procurement area for a potential site location increase in area.

3.2. Opportunity Zones Combining the Landscape Suitability and Competition Indices. The spatial pattern of competition intensity within a $128.8 \mathrm{~km}$ one-way haul distance zone is displayed in Figure 5. Regions that had less than 10\% supply net growth consumed by existing capacity, annual supply net growth greater than 10,000 dry tons/year, and timberland annual growth-to-removal ratio greater than 1.5 were considered least competitive. Regions that had greater than $100 \%$ supply net growth consumed by existing adjusted capacity were considered highly competitive. The criteria to assess the opportunity zones by the combined landscape suitability and competition indices are given in Table 5 .

"High" suitability areas from the landscape suitability index when combined with high competition intensity $(>5)$ resulted in a reduction of 395 ZCTAs, most of which were located in northwest Alabama. Given the aforementioned criteria, a total of 592 ZCTAs were considered highly desirable opportunity zones for forest biomass availability. These preferred zones were located in Central Mississippi, Northern Arkansas, South central Alabama, Southwest Georgia, Southeast Oklahoma, Southwest Kentucky, and Northwest Tennessee (Figure 6).

3.3. Opportunity Zones Combined with BioSAT Model. One potential value to the practitioner from the aforementioned analyses is in the siting of biomass-using facilities. An example of use for practitioners involved in plant siting would be to combine the analyses with the BioSAT model. As cited earlier [26], the BioSAT model (http://www.biosat.net/) can be used to assess more detailed economic information for any particular opportunity zone such as harvesting costs, transportation costs, stumpage costs, marginal cost curves, and so forth. Information related to the producers' marginal costs can be used to derive the important supply curve information necessary for potential users of wood cellulosic feedstocks. This may be important in developing markets such as woody cellulosic renewable energy where detailed assessment of the economic viability of mill location is essential.

In this study the BioSAT model was used to derive more detailed economic information for one of the high suitability opportunity zones located in central Mississippi (Figure 7). For the sake of illustration, the BioSAT model was run using ZCTA 39090 (Kosciusko MS) as the demand location for woody cellulosic feedstocks, specifically southern pine pulpwood (pinus spp.). The associated biobasin for ZCTA 39090 (Kosciusko MS) assuming a 120 mile haul distance is displayed in Figure 8. The associated marginal cost curve for demand ZCTA 39090 (Kosciusko MS) is also displayed in Figure 8. Marginal costs increase from approximately $\$ 48$ to $\$ 66 /$ dry ton over a maximum supply of southern pine pulpwood of 773,096 dry tons.

\section{Conclusions}

Renewable energy is projected to be one of the fastest growing industries in the US agricultural and forest sectors. However, replacing petroleum products with renewable energy presents technical, economic, and research challenges, one of which is the availability of biomass feedstock. This study directly addresses this problem by developing spatial geographic information for potential users of the woody cellulosic feedstocks for a 13-state study region in the Southern United States. The spatial geographic data accounts for landscape features, socioeconomic factors, and competition 


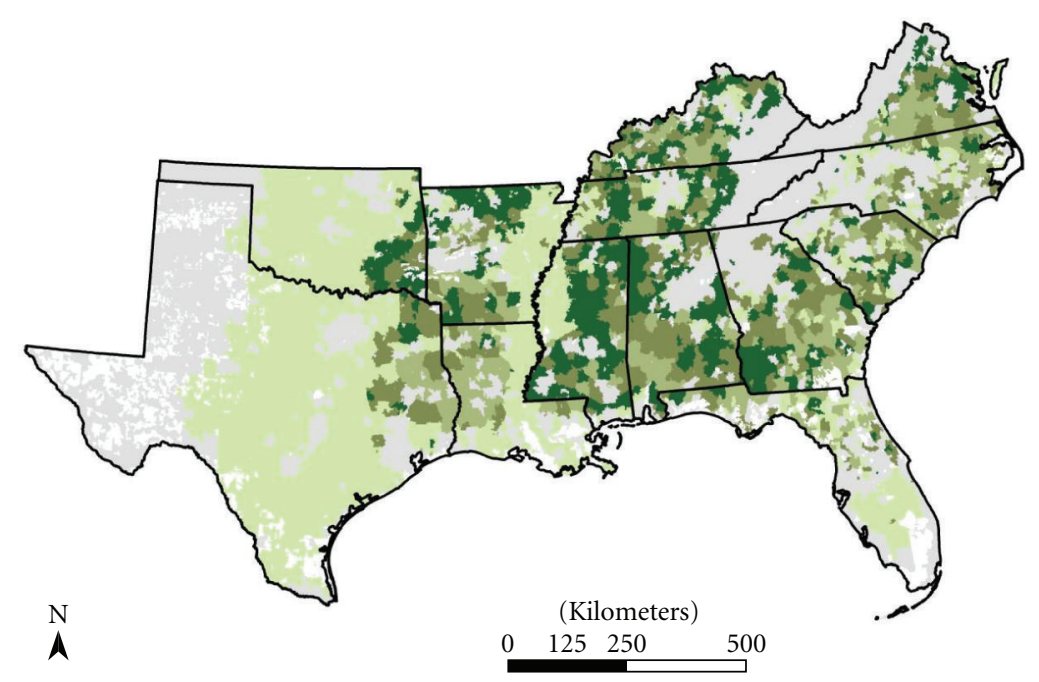

Landscape suitability index of forest biomass

High (987, 5-digit ZCTAs)

Moderate (1,046, 5-digit ZCTAs)

Low (713, 5-digit ZCTAs)

Unsuitable (2,251, 5-digit ZCTAs)

Exclusion (5,019, 5-digit ZCTAs)

FIGURE 4: Opportunity zones for woody biomass-using facilities identified by landscape suitability index in the 13-state study region.

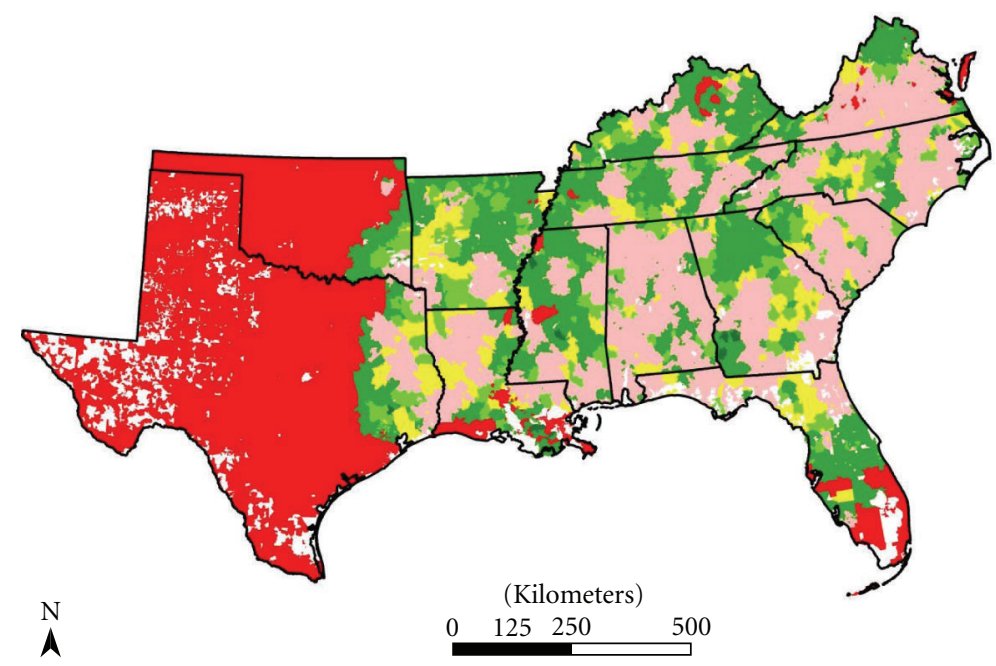

Competition index on resource utilization within a 128.8 one way travel distance

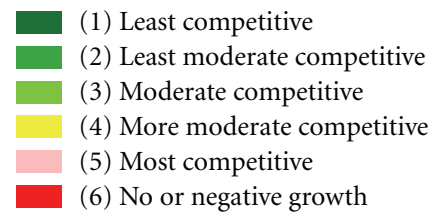

FIgURE 5: Competition index on resource utilization within a $128.8 \mathrm{~km}$ one way travel distance. 


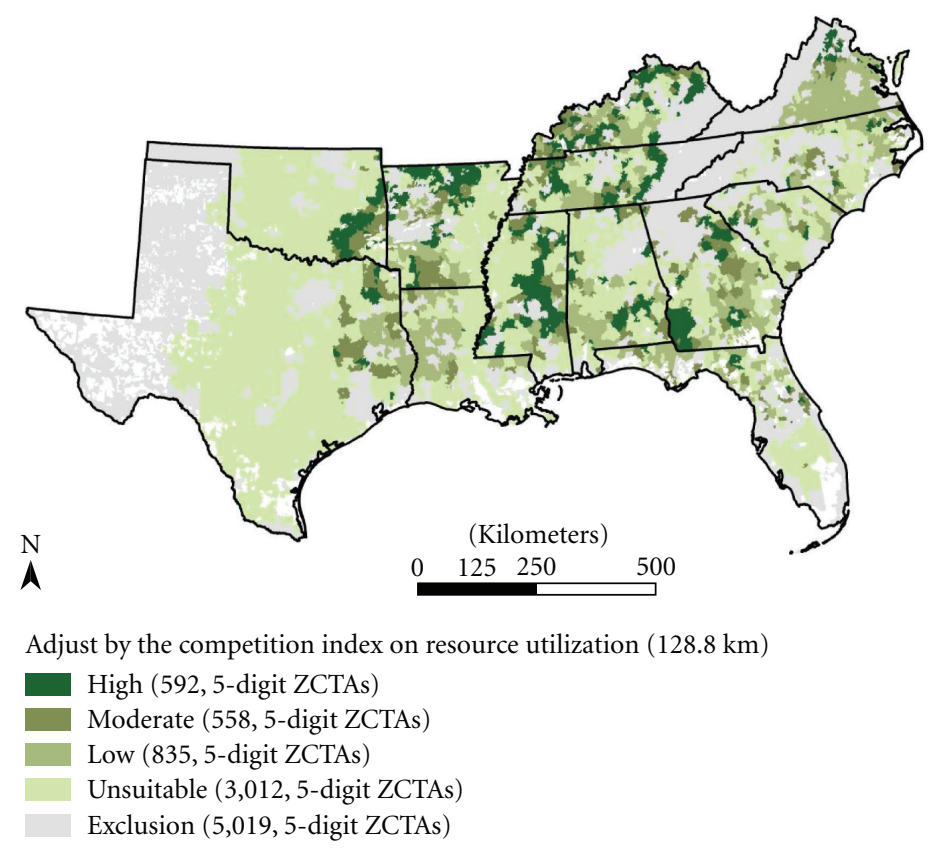

FIgURE 6: Opportunity zones identified by the combined landscape suitability and competition indices in the 13-state study region.

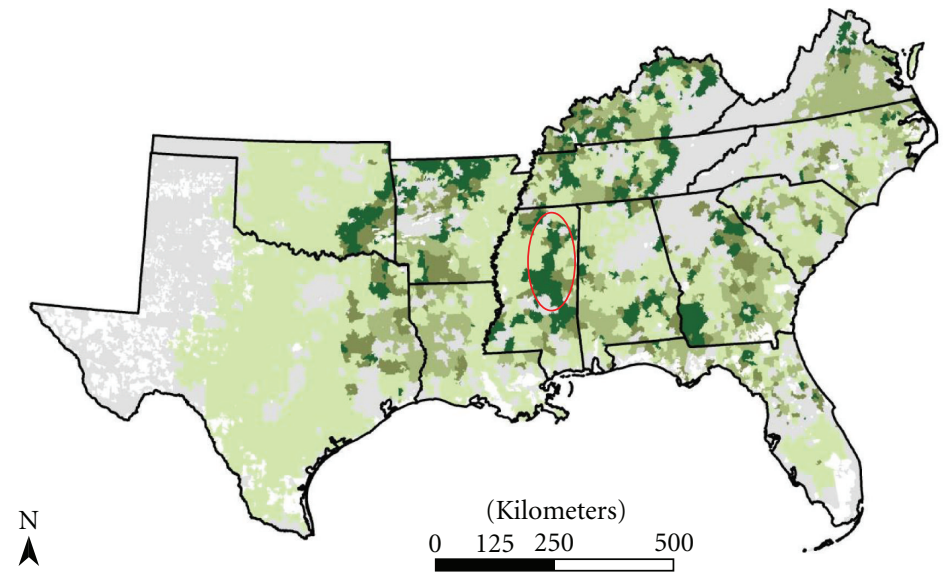

Adjust by the competition index on resource utilization $(128.8 \mathrm{~km})$

FIgUre 7: Opportunity zone in central Mississippi (highlighted in red) for mill location at ZCTA 39090 (Kosciusko MS).

for the resource, organized at the 5-digit zip code resolution. Landscape and competition indices were developed in the study and combining these indices in a spatial geographic context derives a classification of "opportunity zones" for potential users of woody cellulosic feedstocks. A total of 592, 5-digit ZCTAs were considered highly desirable opportunity zones for woody cellulosic feedstocks. These preferred zones were located in Central Mississippi, Northern Arkansas,
South central Alabama, Southwest Georgia, Southeast Oklahoma, Southwest Kentucky, and Northwest Tennessee.

Project work is ongoing in developing short rotation woody crop (SRWC) data layers. The SRWC data layers will incorporate soils data, climatology data, growth modeling, and economic cost analyses. The SRWC data layers will provide dedicated energy crop analyses as a feedstock source for practitioners interested in siting scenarios using SRWC. 


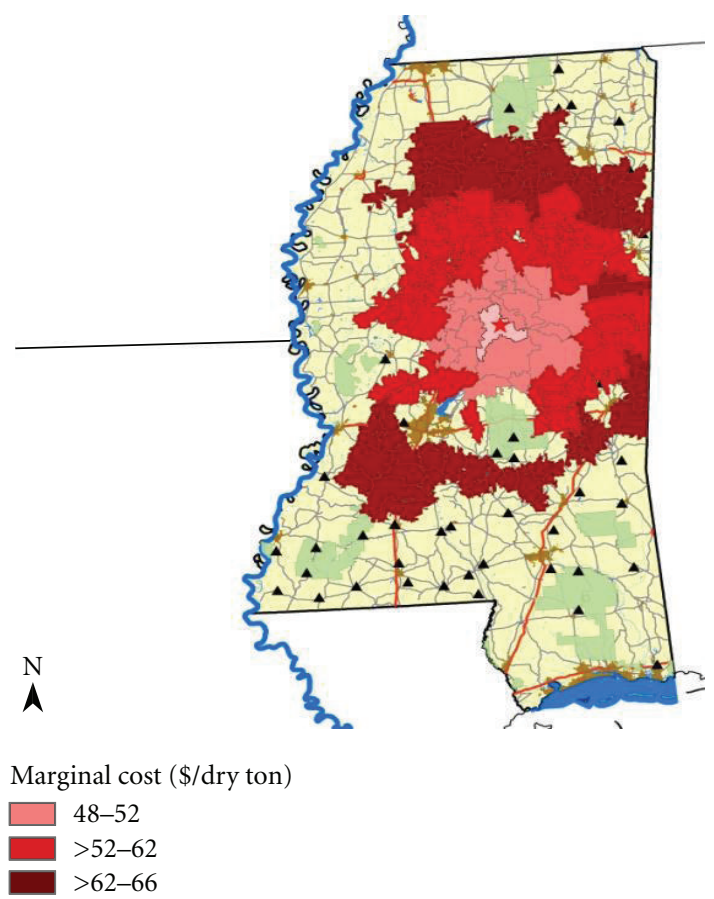

(a)

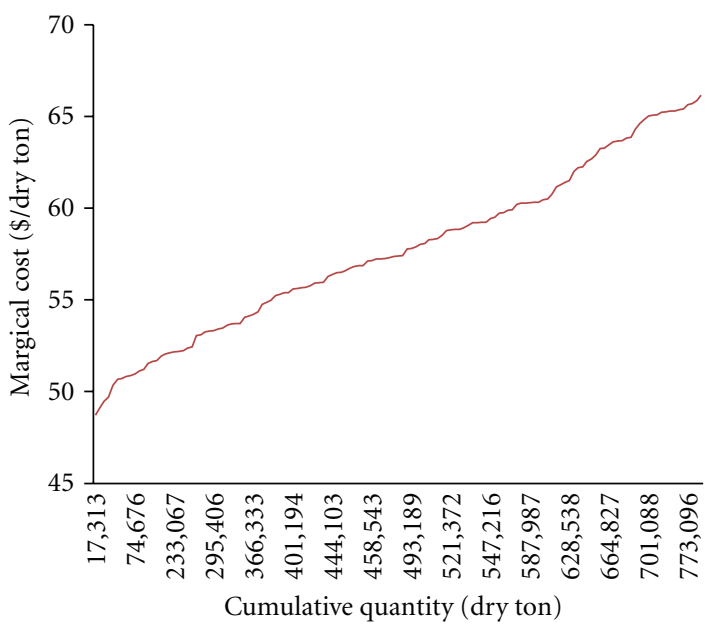

(b)

Figure 8: Spatial representation of biobasin for ZCTA 39090 (Kosciusko MS) and associated marginal cost curve for pine pulpwood (pinus spp.) from the BioSAT model.

\section{Acknowledgments}

This research was funded by US Forest Service Southern Research Station under contract agreement 07-CR11330115-087, Southeastern Sun Grant Center, and University of Tennessee Agricultural Experiment Station.

\section{References}

[1] Energy Information Administration, "International energy outlook, 2008," Report DOE/EIA-0484(2008), http://www .tulane.edu/ bfleury/envirobio/readings/International $\% 20$ Energy\%20Outlook\%2008.pdf.

[2] O. J. Blanchard and J. Gali, "The macroeconomic effects of oil price shocks: why are the 2000 s so different from the 1970s?" in Proceedings of NBER ME Conference on International Dimensions of Monetary Policy, Catalonia, Spain, 2007, http://www.crei.cat/people/gali/pdf_files/bgoil07wp.pdf.

[3] A. Elbehri, The Changing Face of the U.S. Grain System, Economic Research Service. U.S., Department of Agriculture, Washington, DC, USA, 2007.

[4] T. M. Young and D. M. Ostermeier, "IFCHIPSS-the industrial fuel chip supply simulation model," Final Report for Contract with Southeastern Regional Biomass Energy Program as administered by the Tennessee Valley Authority, 1989.

[5] T. M. Young and D. M. Ostermeier, "The economic availability of woody biomass for the southeastern United States," Bioresource Technology, vol. 37, no. 1, pp. 7-15, 1991.

[6] T. M. Young, D. M. Ostermeier, J. D. Thomas, and R. T. Brooks Jr., "Computer model simulates supply, cost of chips," Forest Industries, vol. 118, no. 8, pp. 20-21, 1991.
[7] A. Lunnan, "Agriculture-based biomass energy supply-a survey of economic issues," Energy Policy, vol. 25, no. 6, pp. 573-582, 1997.

[8] M. E. Walsh, "U.S. Bioenergy crop economic analyses: status and needs," Biomass and Bioenergy, vol. 14, no. 4, pp. 341-350, 1998.

[9] M. E. Walsh, "Method to estimate bioenergy crop feedstock supply curves," Biomass and Bioenergy, vol. 18, no. 4, pp. 283$289,2000$.

[10] J. DiPardo, "Outlook for biomass ethanol production and demand," U.S. Energy Information Administration, 2000, http://www.eia.doe.gov/oiaf/analysispaper/pdf/biomass.pdf.

[11] D. G. de la Torre Ugarte and D. E. Ray, "Biomass and bioenergy applications of the POLYSYS modeling framework," Biomass and Bioenergy, vol. 18, no. 4, pp. 291-308, 2000.

[12] D. G. de la Torre Ugarte, B. C. English, R. J. Menard, and M. Walsh, "Conditions that influence the economic viability of ethanol from corn stover in the Midwest of the USA," International Sugar Journal, vol. 108, no. 1287, pp. 152-156, 2006.

[13] D. G. de la Torre Ugarte, B. C. English, and K. Jensen, "Sixty billion gallons by 2030: economic and agricultural impacts of ethanol and biodiesel expansion," American Journal of Agricultural Economics, vol. 89, no. 5, pp. 1290-1295, 2007.

[14] Biomass Research and Development Board, "Increasing feedstock production for biofuels economic drivers, environmental implications, and the role of research," 2008, http://www .usbiomassboard.gov/pdfs/increasing_feedstock_revised.pdf.

[15] Western Governor's Association, "Strategic assessment of bioenergy development in the West-spatial analysis and supply curve development," University of California, Davis, Calif, USA, 2008, http://www.treesearch.fs.fed.us/pubs/34631.

[16] G. Perez-Verdin, D. L. Grebner, C. Sun, I. A. Munn, E. B. Schultz, and T. G. Matney, "Woody biomass availability for 
bioethanol conversion in Mississippi," Biomass and Bioenergy, vol. 33, no. 3, pp. 492-503, 2009.

[17] C. S. Galik, R. Abt, and Y. Wu, "Forest biomass supply in the southeastern United States-implications for industrial roundwood and bioenergy production," Journal of Forestry, vol. 107, no. 2, pp. 69-77, 2009.

[18] U.S. Department of Energy, R. D. Perlack, and B. J. Stokes, "U.S. billion-ton update, biomass supply for a bioenergy and bioproducts industry," ORNL/TM-2011/224, Oak Ridge National Laboratory, Oak Ridge, Tenn, USA, 2011.

[19] R. D. Perlack, L. L. Wright, A. F. Turhollow, R. L. Graham, B. J. Stokes, and D. C. Erbach, "2005Biomass as feedstock for a bioenergy and bioproducts industry: the technical feasibility of a billion-ton annual supply," Publication DOE/GO-1029952135/ORNL TM-2005/66, OAR Ridge National Laboratory, OAR Ridge, Tenn, USA, http://feedstockreview.ornl.gov/ pdf/billion_ton_vision.pdf.

[20] U.S. Census Bureau, "2010 Census ZIP code tabulation areas [data file],” 2010, http://www.census.gov/geo/ZCTA/zcta .html.

[21] U.S. Forest Service, "Lands in public preserves [data file]," Personal contact on 08/2011, 2009.

[22] U.S. National Land Cover Database, "Multi-resolution land characteristics consortium [Data file]," 2006, http://www.mrlc .gov/nlcd2006.php.

[23] U.S. National Elevation Dataset, "National elevation dataset 1 arc second [data file]," 2010, http://seamless.usgs.gov/ned1 .php.

[24] U.S. Department of Agriculture National Agricultural Statistics Service, "Census of agriculture: farm net income [data file]," 2007, http://quickstats.nass.usda.gov.

[25] U.S. Environmental Protection Agency, "Ecoregions of the United States [data file]," 2011, http://www.epa.gov/wed/ pages/ecoregions/level_iii_iv.htm.

[26] J. H. Perdue, T. M. Young, and T. G. Rials, "The biomass site assessment model-BioSAT," Final Report For U.S. Forest Service, Southern Research Station, The University of Tennessee, Knoxville, Tenn, USA, 2011.

[27] B. J. Butler, Z. Ma, D. B. Kittredge, and P. Catanzaro, "Social versus biophysical availability of wood in the Northern United States," Northern Journal of Applied Forestry, vol. 27, no. 4, pp. 151-159, 2010.

[28] D. N. Wear, R. Liu, J. M. Foreman, and R. M. Sheffield, "The effects of population growth on timber management and inventories in Virginia," Forest Ecology and Management, vol. 118, no. 1-3, pp. 107-115, 1999.

[29] C. J. Chu, F. T. Maestre, S. Xiao et al., "Balance between facilitation and resource competition determines biomassdensity relationships in plant populations," Ecology Letters, vol. 11, no. 11, pp. 1189-1197, 2008.

[30] J. Weiner, P. Stoll, H. Muller-Landau, and A. Jasentuliyana, "The effects of density, spatial pattern, and competitive symmetry on size variation in simulated plant populations," American Naturalist, vol. 158, no. 4, pp. 438-450, 2001.

[31] J. Weiner and C. Damgaard, "Size-asymmetric competition and size-asymmetric growth in a spatially explicit zone-ofinfluence model of plant competition," Ecological Research, vol. 21, no. 5, pp. 707-712, 2006.

[32] M. Kimsey, D. Page-Dumroese, and M. Coleman, "Assessing bioenergy harvesting risks: geospatially explicit tools for maintaining soil productivity in Western US forests," Forests, vol. 2, no. 3, pp. 797-813, 2011.
[33] Food and Agriculture Organization of the United Nations (FAO), "Definitions of forests [definition]," 2000, http://www .fao.org/DOCREP/005/Y4171E/Y4171E10.htm.

[34] United Nations Framework for Climate Change Convention (UNFCCC), "Definitions of forests [definition]," 2001, http://www.fao.org/DOCREP/005/Y4171E/Y4171E10.htm.

[35] F. R. Greulich, D. P. Hanley, J. F. McNeel, and D. Baumgartner, A Primer for Timber Harvesting, Washington State University Extension, Pullman, Wash, USA, 1999, http://faculty.washington.edu/greulich/Documents/eb1316.pdf.

[36] U.S. Census Bureau, "The urban and rural classifications," Chapter 12, 2010, http://www.census.gov/geo/www/GARM/ Ch12GARM.pdf.

[37] R. I. McDonald, G. Motzkin, M. S. Bank, D. B. Kittredge, J. Burk, and D. R. Foster, "Forest harvesting and land-use conversion over two decades in Massachusetts," Forest Ecology and Management, vol. 227, no. 1-2, pp. 31-41, 2006.

[38] The World Bank, "Transports: roads \& highways [definition]," 2011, http://www.worldbank.org/html/extdr/thematic.htm.

[39] B. J. Butler and S. L. King, "Assessment and mapping of forest parcel sizes," in Proceedings of the 5th Annual Forest Inventory and Analysis Symposium, New Orleans, La, USA, 2003, http:// www.treesearch.fs.fed.us/pubs/14259. 

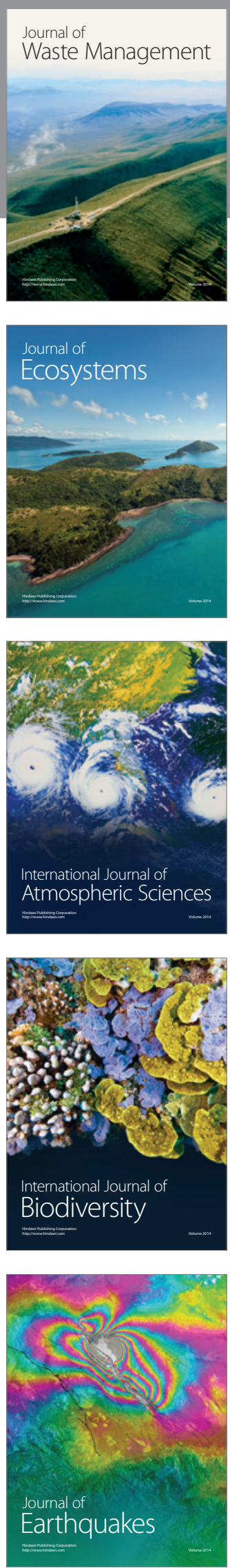
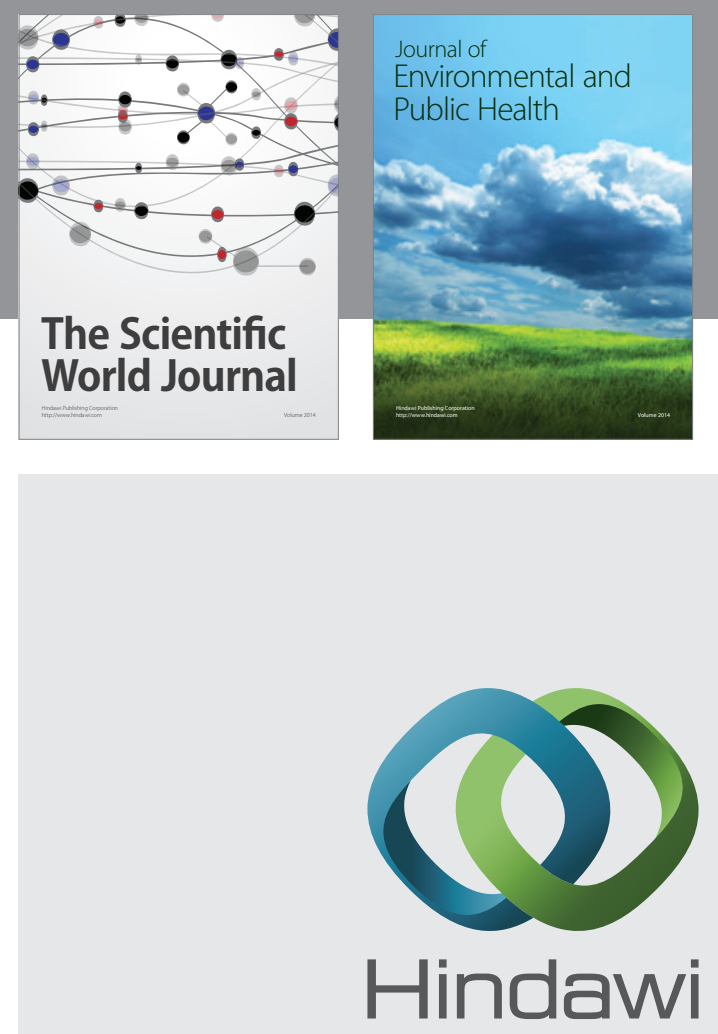

Submit your manuscripts at

http://www.hindawi.com
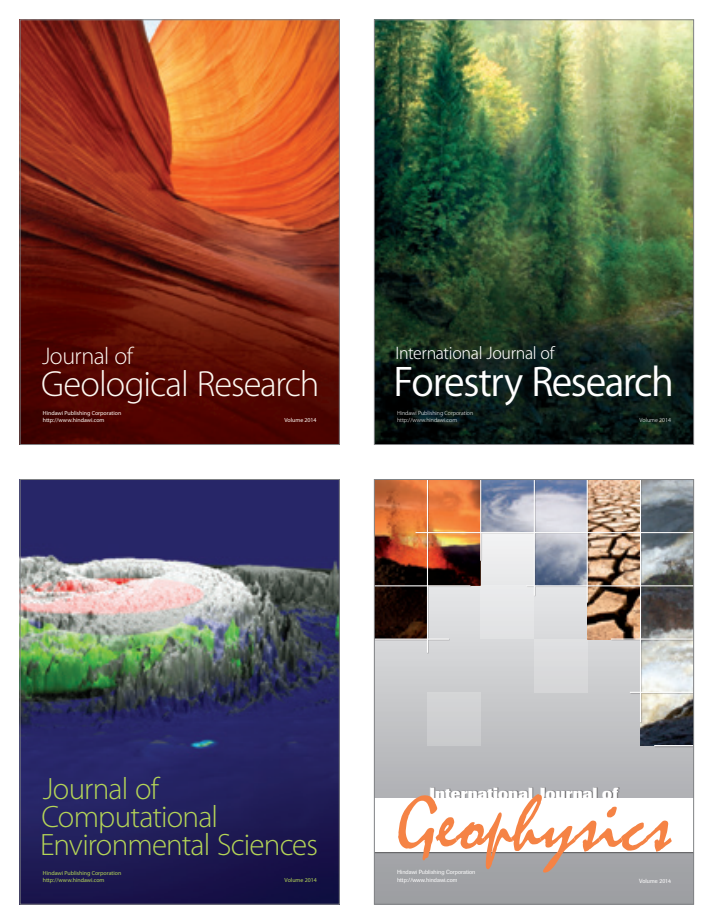
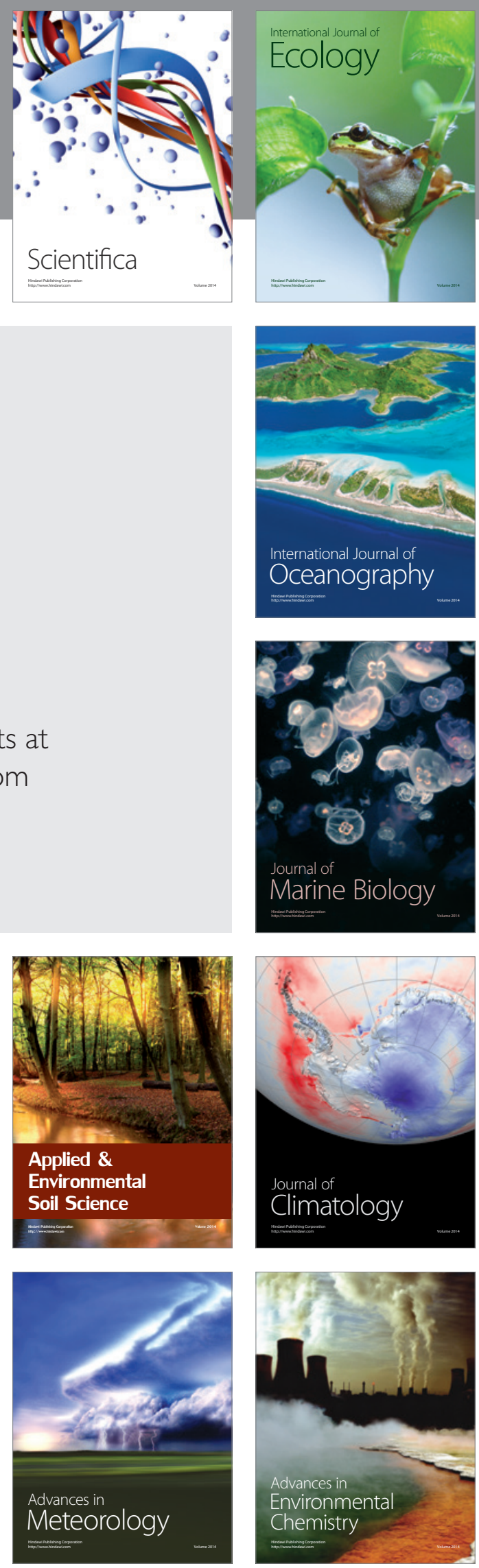